\title{
LOCAL WISDOM OF THE BAJO TRIBE AND ITS ACCULTURATION ON ISLAMIC SHARIA: A CASE IN TOMINI BAY-INDONESIA Lahaji $^{1}$, Muhammad Obie ${ }^{2 *}$

\author{
${ }^{1}$ Faculty of Sharia, State Islamic University of Sultan Amai Gorontalo, Indonesia, ${ }^{2}$ Department of Sociology, State
} Islamic University of Sultan Amai Gorontalo, Indonesia. \\ Email: *obiclimber@gmail.com
}

\author{
Article History: Received on $17^{\text {th }}$ November 2019, Revised on $05^{\text {th }}$ February 2020, Published on $29^{\text {th }}$ February 2020 \\ Abstract
}

Purpose: This study analyzed local wisdom of the Bajo Tribe and its acculturation on Islamic Sharia. Furthermore, it analyzed the practice of pamali and mamiakadilao as local wisdom of the Bajo tribe, and whether the existence of Islamic Sharia diminishes the practice of local wisdom, or precisely accompanies the local wisdom of the Bajo people.

Methodology: A case study method has been used for the study. The selection of informants was by purposive sampling and snowball techniques. The data collection was through in-depth interviews and passive participation observation. The data analysis was done qualitatively.

Main Findings: The Bajo had local wisdom in the form of pamali and mamiakadilao which were institutionalized in traditions and customs. Pamali is an ethic of the Bajo people in building relationships with their natural environment. While, mamiakadilao is a grouping of the Bajo when fishing, namely the palilibu, bapongka, and sakai groups. When the Bajo accepted Islamic sharia, it did not eliminate their original beliefs. These two belief systems live side by side. The Bajo accepted Islam as their religion, but at the same time still hold fast and practice their ancestral heritage.

Implications: Understanding the local wisdom of the Bajo Tribe, as well as its acculturation on Islamic Sharia.

Novelty: The acceptance of Islam as a new religion for the Bajo does not diminish existing local wisdom. Bajo people embrace Islam as a new religion, but they do not abandon ancestral traditions. The entry of Islamic sharia is to enrich the local wisdom of the Bajo tribe.

Keywords: Local Wisdom, Tradition, Bajo Tribe, Acculturation, Islamic Sharia, Tomini Bay.

\section{INTRODUCTION}

Each ethnic group has customs and traditions that are institutionalized in the practice of the lives of its people. Customs and traditions that are held in high esteem have distinctions that distinguish them from other ethnic groups or groups of people. In practice, the peculiarities of customs and traditions in every society have local values. Local wisdom is built on social values that are upheld in the social structure of the community itself and has functioned as guidelines, controllers, and signs to behave in various dimensions of life, both when dealing with others and with nature ( $\underline{\text { Santoso, }}$ 2006). Local wisdom can manifest in various forms such as ideas, values, norms, and rules in the realm of culture, while in social life can be in the form of religious systems, social systems and organizations, knowledge systems, livelihood systems, and systems of technology and equipment (Koentjaraningrat, 1964) (Renjaan et al,2013) ( $\underline{\text { Zulharman et al, }}$ 2017) (Sukmayadi, 2018) (Ali, 2017) (Reza et al., 2017).

Research related to tradition and local wisdom has been carried out by experts with various topics of study, including: bapongka, the cultural system of the Bajo in preserving coastal resources (Artanto, 2017); boat in the Bajo pamali: an overview of Halliday's social semiotics (Uniawati, 2014); local wisdom values in water management (Sulastriyono, 2009); the existence of local wisdom in forest edge farmers in maintaining the sustainability of forest resource ecosystems (Santoso, 2006); local wisdom in the utilization and preservation of coastal resources (Zulkarnain, 2009); local wisdom-based fisheries management policies (Sulaiman, 2010); ecological intelligence in local wisdom (Utina, 2012); local wisdom in managing natural resources and the environment (Kafiar, 2013); local wisdom in environmental conservation (Thamrin, 2013); farming and local wisdom (Putra, 2013); local wisdom of indigenous peoples in the prevention of forest and land fires (Syaufina et al, 2013); local wisdom culture in the governance and development of the urban environment (Gunawan et al, 2014); the role of customary institutions in the preservation of local wisdom (Alus, 2014); Local wisdom of the village community in managing natural honey (Kael et al, 2015); and study of local wisdom for tourism development (Indriastjario et al, 2015).

Tradition as local wisdom is a culture of a society that, if it comes in contact with other cultures, will experience change, both in acculturation, assimilation, and diffusion. Through cultural contact, a higher and more active culture will influence lower and passive cultures. At the individual level, loss of cultural identity can occur due to intercultural contact. However, not all contacts will cause a loss of cultural roots. A group may separate itself from other groups, and its members have a chauvinistic attitude, ethnocentrism, and stereotypes towards other groups. As a result, their cultural identity becomes even stronger through cross-cultural contact (Dayakisni, 2008). The more likely possibility for intercultural contact at the group level is the existence of integration. It occurs when different groups maintain their cultural identity in several ways but give rise to other rewards on aspects in the name of the group (Bochner, 1988). 
This research fills the gap of the current study by focusing on the analysis of local wisdom of the Bajo tribe and its acculturation on Islamic Sharia. The discussion of local wisdom is related to the entry of Islamic sharia as the only religion for the Bajo. The authors analyzed more deeply about 1) the practice of pamali and mamiakadilao as local wisdom of the Bajo tribe; 2) the practice of pamali and mamiakadilao before the Bajo people embrace Islam; 3) whether the existence of Islamic sharia diminishes the practice of local wisdom, or precisely accompanies the local wisdom of the Bajo people.

\section{RESEARCH METHODS}

This research used a qualitative approach to the case study method. The case study method is intended to focus more on an intensive and detailed case (Surakhmad, 1982). The case study in this study was the local wisdom of the Bajo and its acculturation on Islamic Sharia. Meanwhile, data collection was done through in-depth interviews and passive participation observation.

Data sources were classified into primary data and secondary data. Primary data were obtained from informants through in-depth interviews and passive participation observations, while secondary data were obtained through document studies in the form of previous research results. The selection of informants was made by purposive sampling (Moleong, 2007) by selecting key figures, such as village heads and custom leaders. The selection of informants was then carried out using the snowball technique, which was after being interviewed the village head and the customary head to be asked to show who else knew about the case being studied. The data analysis then was done qualitatively.

\section{RESULTS AND DISCUSSION}

\section{Pamali and Mamia Kadilao as Local Wisdom of the Bajo Tribe}

Pamaliin Bajo society is an oral tradition that utilizes the potential of language to say an expression or discourse which includes certain beliefs and prohibitions to avoid certain acts or behaviors because they contain an effect (Uniawati, 2014) (Rahmadani et al., 2012). Pamali is an ethic of the Bajo people in building relationships with their natural environment. The Bajo people have conservation ethics that treat nature wisely, without over-exploitation. In the pamali there is an environmental ethic that must not be violated because if it is violated, the culprit will get a katula. Katulais an ancestral punishment for those who break the pamali, in the form of illness, disaster or get a bad future.

Some Bajo pamali related to conservation ethics, for example, pamali cut down mangrove trees carelessly, and pamali throws into the forest area carelessly. The two pamali contain messages related to environmental preservation. Pamali felling trees carelessly is a message that prohibits damaging forests, but that does not mean that they should not take advantage of the necessities of life. Likewise, pamali throwing into the forest carelessly containing messages is prohibited from damaging the ecosystem in the forest. It contains the message that in the forest area not only consists of a collection of trees in the form of mangroves, but also there are other ecosystems in the form of birds, fish, and others. Throwing into the forest carelessly is feared to damage the other ecosystems (Obie, 2016).

Pamali is a conservation ethic, which was also practiced by the Bajo when fishing. Some pamali cannot be done either by the family left behind or those who are at sea. Pamali is forbidden to throw into marine waters such as; sea cucumber washing water, wood charcoal or kitchen ash, cigarette butts and ash, chili water, ginger, and orange juice, as well as a ban on washing cooking utensils in sea waters. Both washing water and materials should be collected and then dumped on land. There is also a prohibition on eating turtle meat; if this is violated, it can wreak havoc, hurricane disasters, disturbances of evil spirits; even those who go to sea do not get any results. Sea turtles are believed to help many people who experience calamities; therefore, these animals should not be killed. Bajo people (the older generation) still believe in certain coral groups as a place to inhabit the spirits of their ancestors. Parents forbid family members from catching fish and other biotas around coral clusters, except first having to perform certain rituals by preparing offerings for ancestors. Pamali contains a message, among others: the prohibition of disposing of waste into marine waters because it can cause marine pollution and disrupt the life of the biota. Remove kitchen ash, cigarette ash, chili water, ginger water into deadly waters for jellyfish. Frying pan and cooking utensils contain charcoal and soot, which can cause cloudy water, which can disrupt seagrass and coral reefs - the presence of pamali when fishing is an effort to use marine resources in a certain period. Prohibition for residents to kill sea turtles, and to approach certain coral reef groups contains the value of preserving animals to support the existence of marine and coastal aquatic ecosystems (Utina, 2012).

There were times when the Bajo were prohibited for going to the sea, like when they were at the time of the masaro. Masaro is a traditional ceremony of the Bajo tribe that is held every year to refuse disaster. Three days before and after the masaro every Bajo is prohibited from going down to the sea. During that time, the Bajo were concentrated following the traditional ceremony.

\footnotetext{
" Masaro must be followed by all Bajo people. Three days before and after the implementation of msaro, Bajo people were prohibited from going to sea. Masaro is marked by the installation of a white flag before sunrise. The white flag must not be installed after the sun rises. The masaro ingredients are all kinds of fruit on land; one chicken lives white, one chicken has been cooked, rice is pulu, three seeds are maleo eggs, there are ringgits and statues of sea rulers. The materials are transported into small boats and then released to the free sea"(Sompah, 2018).
} 
The Bajo also believe in the prohibition of going to the sea if there is grief, besides masaro. It shows the existence of social solidarity. There is a spirit of collectivity that is still upheld by the Bajo, who are institutionalized in the pamali tradition. Likewise, if children at home cry, then their father, for a moment has not stepped out to sea. Likewise, pamali rebuked when someone was sailing feeling or seeing strange things.

"We 'pamali' commented on strange things that were happening around us, whether to reprimand in inappropriate language. We believe that every incident has subtle spirits, so if reprimanded it can make them angry and have a bad impact on those who reprimand" (Sompah, 2018)

The Bajo has close ties to the coast and the sea. For centuries they have lived wandering in the ocean, moving around with traditional boat transportation. Boats and the sea are their cultures. That is why the Bajo people cannot be separated from the sea and boats. Like a fish that has a dependency on water, the Bajo also has a dependence on the coast and the sea. The Bajo tribe form distinctive wisdom with coastal and marine resources. It is believed to be a form of adaptation of the Bajo people with their natural environment.

The pattern of local wisdom generally places cultural capacity, systems of knowledge and technology, religion, tradition, and social capital (ethics and environmental wisdom, norms, and legal institutions) as something extraordinary in order to utilize resources. The cultural capacity is used to balance the utilization and estimated potential. The concept is the goal of sustainability as an essential consideration for local communities in utilizing resources (Sulaiman, 2010).

The Bajo people who inhabited Tomini Bay since the 1800s have local cultural values and traditions that have traditionally respected the natural elements as part of their lives. The Bajo live side by side and peace with nature. For this reason, the Bajo feel they have a natural environment, so they protect and preserve it. It can be said that for reasons of cultural values and tradition, the Bajo have coastal and marine customary rights in Tomini Bay (Obie, 2015). So, it is not an exaggeration to say that the Bajo are included in the natural human group. One characteristic of human nature is that the relationship between humans and nature is so melting, united, that humans are part of the natural order. As a result, ethnic religion is the religion of nature. That is, nature is believed to have power, as well as a magical power, which on the one hand provides life and livelihood; while, on the other hand, haunted and frightening nature (Fallding, 1974).

The Bajo see coastal and marine in several functions. That view then forms wisdom in interacting with its environment - first, the ritual function. The coast and sea for the Bajo are understood as a sacred area. Various rituals are carried out in the sea, for example, when trying to catch fish and marine products, marriage, childbirth, circumcision, death, and traditional medicine. When trying to catch fish, Bajo people first carry out rituals. According to the Bajo, the ritual before going to sea was very important for two reasons: first, asking for the protection of the spirit (god) of the sea in order to avoid a calamity; and second, asking for large catches. Usually, the ingredients prepared in this ritual consist of betel nut, betel leaf, whiting, and cigarettes. Likewise, when conducting marriages, the Bajo carry out rituals in a traditional procedure called mingkolo.

Furthermore, when the child is born, the Bajo welcomes him/her with various rituals. The birth process in the Bajo tribe is assisted by a shaman called Sandro. Shortly after birth, the Sandro rubs blood taken from the placenta on the baby's lips, forehead, and cheeks. Sandro does this with a spell reading. It is so that the baby is long-lived. Likewise, the placenta for the Bajo believes it as a sister, a baby twin sister who must be treated specifically in a ritual. The umbilical cord, which has been wrapped in mats, along with tobacco, cigarettes, betel nuts, and salt are released into the seafloor. In order for the baby not to fall ill, the person who releases the placenta to the sea must read the spell repellent, "do not look at us, we throw something that is not for you" (Zacot, 1982).

They are mainly related to the ritual of healing the disease carried out by the duata, namely part of the traditional institutions that administer traditional rituals and traditional treatments. Traditional rituals and traditional treatment carried out by the two institutions are inseparable from the harmony of the relationship between the Bajo tribe and its natural resources. Thus, rituals and duata-style treatments cannot be separated from the sea and coastal and marine natural resources. It is because the Bajo believe that every ecosystem on the coast and sea has supernatural creatures in the form of spirits. Spirits who live in mangrove areas guard mangrove ecosystems; coral reef ecosystems are guarded by spirits specifically coral reefs; seagrass ecosystems guarded by spirits, specifically guardians of seagrasses, and even the sea is guarded by a special sea guardian spirit. The Bajo believe that if the ecosystems on the coast are disturbed, then the spirits will show their wrath. Therefore, Bajo is very wise in treating these existing ecosystems. The Bajo people believe that all kinds of diseases that arise among them come from the guardian spirits of those ecosystems. Thus, whenever there were sick people among them, the duata immediately gathered to identify where the disease came from (Obie, 2016). The treatment of diseases by duata cannot be separated from offerings, namely to feed the spirits which are considered to have been disturbing, causing the Bajo to be sick. By providing offerings, the Bajo hope that their illness will be as red as healed.

Second, ecological functions. The Bajo has a close relationship with their natural resource environment so that they know the ecological functions of the mangrove as a place to spawn and develop fish. Besides, mangroves also function 
to reduce wind exposure and prevent erosion and become a habitat for endemic Sulawesi macaques (Macaca) and reptiles. They understand the economic functions of mangroves used for firewood, building materials, net dyes and cosmetics, traditional medicines, places to look for various types of fish, shrimp, crabs, honey bees, and others. They also understand that mangrove degradation causes coastal erosion and decreases in fish stocks (De Block, 2009).

Third, coastal and marine natural resources provide life. In this context, coast and sea become very vital for the Bajo people; in fact, it can be said to be a marker of the beginning of a life cycle. Coastal and sea are very vital and become a keyword in the life of the Bajo. Bajo depends on their life and livelihood on coastal and marine resources. Since its presence in Tomini Bay, the Bajo tribe is free to take up the potential of coastal and marine resources in the bay. They catch fish and look for other marine products, then sell them to the beach or the nearest market on land (Obie et al, 2015). The Bajo see that the coastal and marine resources in Tomini Bay are the basis of their livelihood, so that is where they live and search for marine products. They live with nature and exploit it to the extent of their livelihood needs without leaving their preservation.

The emotional closeness of the Bajo with coastal and marine resources raises a tradition called mamiakadilao. The tradition of mamiakadilao is a grouping of the Bajo when fishing for a certain time and the type of boat used. There are three groups of this tradition, namely: palilibu, bapongka, and sasakai. Palilibu is the custom of fishing using a shop type boat which is driven by paddles, this fishing activity is only in one or two days then returns to the settlement to sell the catch, and some are enjoyed with the family. Bapongka or also called babangi is an activity of fishing for several weeks or even monthly using a large boat measuring approximately four times two meters called Leppa, often involving families (wives and children) and some even giving birth to children on a boat, and the critical thing to obey during bapongka is taboos (Utina\&Alwiah, 2008). Meanwhile, sasakaiis the custom of fishing using several boats for several months with a range between islands (Harun, 2011).

"Most fishermen here are palilibu and pongka. We used to go home early at night, and there were times when we went down late in the morning. Some are longer than that, going down to sea until a week or even a month back. The Sakai fishermen are almost not here because we have settled. Sakai fishermen are only on the island, and they go down to the sea at the same time move all the places to take turns and their wives and children"(Pasandre\&Sompah, 2018).

\section{Islamic Sharia in the Local Wisdom of the Bajo Tribe}

Bajo people accepted Islamic Sharia from Malikussaleh, the Sultan of Aceh, in the 13th century. Malikussaleh entrusted the Bajo to become fleet warriors, drove Islamic publishers to the eastern hemispheres, and became boat crews and captain of the Islamic traders. The meeting of the Bajo with the Sultan of Malikussaleh made them accept Islam as a belief alongside their original beliefs (Baskara, 2016). These two belief systems live side by side. However, it does not mean that Islam does not try to fight animism that has been well entrenched in the beliefs of the Bajo (Zacot, 1982). When Islamic broadcasting entered the Bajo community which deified the forces of nature and spirits, Islamic values did not eliminate their original beliefs. The Bajo accept Islam so that all Bajo people are Muslim. Even so, the Bajo people who have been Muslim do not abandon their previous beliefs. Over time, the spells commonly used in rituals and in treating diseases are gradually entered by the words tasbih, tahlil, and tahmid (Islamic Sharia).

Circumcision ceremonies for boys and girls are Islamic sharia that practice in the Bajo community is juxtaposed with ancestral beliefs. Ritual materials such as betel lime and betel nut are ritual materials commonly used when going to sea or rituals to drive away evil spirits that interfere with citizens, also used in circumcision ceremonies. The strength of Islamic Sharia in this circumcision ceremony can be seen when shortly after being circumcised; the child recited the sentence "Allahu massalihalaasaidina Muhammad" loudly. Similarly, the hairdressing ceremony or aqiqah is Islamic sharia whose implementation in the Bajo community is also juxtaposed with ancestral beliefs. The beliefs of the ancestors in question are beliefs in matters of animism and the supernatural so that the traditional rituals are manifested for their service to gods and spirits that are united with their natural resources.

Islamic Sharia, in traditional rituals of the Bajo, can also be seen at the death ceremony. Like the Islamic community in general, warnings accompanied by ghost prayers on the third, seventh, forty, etcetera, are also found in the Bajo community. This ritual is led by a priest who specifically arranges matters relating to religion. A priest accompanied by one of the heirs of a deceased person first goes to the grave to pray and then continues with the ritual carried out at the funeral home. The third day's ritual, goal, etcetera, is done not free from the understanding that the spirit of the deceased still has an attachment to the world. Seven days after the spirit died, people died even believed to be still in the funeral home. Therefore, this time interval is continuously carried out by the prayer of the soul and tahlil. Death rituals are also held when entering the holy month of Ramadhan and Eid al-Fitr. The Bajo people believe that entering the feast of Eid al-Fitr spirit, the deceased person wants to visit his family in the world, so they need to go to his grave to be invited to come to the house of his living family.

Such an understanding is not pure Islamic Sharia. Rituals relating to spirits and spirits guarding natural objects are the beliefs of ancestors who passed down before the arrival of Islam. As well as pamali and mamiakadilao traditions, the entry of Islamic Sharia did not eliminate the practices of the ancestors. To integrate conducive social life, local wisdom based on ancestral heritage on the one hand, as well as Islamic sharia, which are the religions they hold in the Bajo tribe, 
there is a relationship between customary institutions, religious institutions, and state institutions (government). A traditional head leads traditional institutions in which there are duata and sandro. This traditional institution has the role of regulating customary affairs in the form of traditional rituals, healing of sick people, prevention of diseases, and others. Meanwhile, religious institutions are led by a priest who specializes in managing Islamic religious practices within the Bajo Tribe community. The state institutions led by a village head, in addition to regulating village government affairs, also became the general responsible for the ongoing social life in the village community.

These three institutional systems, despite having their respective roles and functions, they have something that is equally regulated and sanctioned by religion, tradition, and government officials, namely the relationship between men and women, especially between youth and young women. In addition to moral sanctions, regulations play a role in protecting women. If a young man acts harshly on a girl, the girl can complain to the customary council, to the priest, or the village head. The young man will be fined, and the fine will be higher if the young man is not a Bajo. If a girl is pregnant out of wedlock, her boyfriend must pay a fine. Furthermore, customary councils and religious institutions jointly require them to get married (Zacot, 1982).

Both traditional institutions and religious institutions are usually involved together in a traditional ritual, as well as religious activities sometimes involving traditional institutions. The village government is responsible for social stability when the ritual takes place. Hairdressing and circumcision ceremonies, for example, are Islamic sharia, which in practice follow traditional rituals. Ritual materials that are used by traditional institutions as the worship of spirits or exorcism ceremonies when there are sick people, such as betel nuts and betel lime, are also used in hairdressing and circumcision ceremonies. Likewise, the commemoration of the Maulid Nabi in its implementation is juxtaposed with Bajo's traditional rituals. As for the influence of Islamic sharia in traditional institutions, for example, spells spoken in the implementation of rituals that were originally pure in the Bajo language were then inserted into the words tahlil, tahmid, and takbir.

"There are so many Bajo spells in worshiping spirits guarding coastal resources, such as worshiping mangroves, coral reefs, the sea, and so on using the language of the Koran" (Pasandre, 2017)

Islam, which is the only religion for the Bajo, is enough to color their daily lives. The activities of the Bajo in earning a living do not make them negligent in carrying out five daily prayers. When the Bajo are at sea and are heard the call to prayer, especially coastal Bajo fishers, then they will immediately pray even on the boat.

"When the Bajo hears the call to prayer, he will pray for a while, even though he is fishing, he will pray on the boat, especially those who are not fishing" (Pasandre\&Sompah, 2018)

There is a mosque in the Bajo settlement and is the only place of worship available. Every time the prayer time comes, it is crowded with Bajo people to pray in the congregation. The better understanding of the Bajo people about Islam is supported by the increasing prevalence of Islamic broadcasting in this community. Besides, more and more Bajo children continue their education at college.

\section{CONCLUSION}

The close relationship between the Bajo people and coastal and marine natural resources creates wisdom in the form of the pamali tradition, namely the ethics of the Bajo people in developing relationships with their natural environment. In the pamali, there is an environmental ethic that must not be violated because if it is violated, the culprit will get a Katula(negative impact), which is the punishment of the ancestors for those who break the pamali (prohibition), in the form of illness, disaster, or get a bad future. The attachment of the Bajo people to coastal and marine resources also led to a tradition called mamiakadialo. The tradition of mamiakadialo is a grouping of Bajo people when they go to sea for a particular period of time, and the boat used, namely the palilibu, bapongka, and sasakai groups.

The local wisdom of the Bajo is institutionalized in customs which are led by customary leaders. Within the customary institutions, there are duata and Sandro. Duata specifically takes care of traditional rituals and traditional treatments, while Sandrotakes explicitly care of labor. When Bajo accepts Islamic Sharia as a new religion for them, Islamic values do not eliminate their original beliefs. These two belief systems live side by side. A customary head leads customary institutions while a priest leads religious institutions. Both institutions are usually involved together in a traditional ritual, as well as in religious activities that also involve traditional institutions. Even so, Islamic broadcasting continues to strive to fight animism that has been well entrenched in the beliefs of the Bajo.

\section{LIMITATIONS AND STUDY FORWARD}

Local wisdom and cultural acculturation of the Bajo tribe which is the case of this research is only the Bajo Tribe in Tomini Bay. Yet in reality, there are many Bajo tribe communities who live above sea surface in the Indonesian archipelago. Therefore, it still needs further research on the local wisdom of the Bajo tribe and its acculturation of Islamic Sharia that inhabit Indonesian waters on other islands.

\section{IMPLICATIONS}

This research has implications both for the development of sociological theory, specifically the theory of cultural acculturation, as well as policymakers for the government, both national and local governments. Understanding of 
cultural acculturation in this research can be the basis of studies for the development of sociological theory. Meanwhile, the results of this study can also be important information for the government in formulating policies relating to indigenous peoples, especially the Bajo tribe.

\section{CO-AUTHOR CONTRIBUTION}

Co-authors together with the main authors carried out data collection, conducted observations, interviewed the informants, and conducted literature reviews. In addition, the co-author also assisted the main authors in analyzing data qualitatively.

\section{ACKNOWLEDGMENT}

The authors would like to thank profusely to the leadership of the State Islamic University of Sultan Amai Gorontalo Indonesia, who had funded the conduct of this research.

\section{REFERENCES}

1. Ali, M. (2017). Mengkomunikasikan Pendidikan Dan Melestarikan Kearifan Lokal Orang Bajo. INFERENSI Jurnal Penelitian Sosial Keagamaan, 11(1), 187-206. https://doi.org/10.18326/infsl3.v11i1.187-206

2. Alus, C. (2014). Peran Lembaga Adat Dalam Pelestarian Kearifan Lokal Suku Sahu Di Desa Balisoan Kecamatan Sahu Kabupaten Halmahera Barat. JURNAL ACTA DIURNA, 3(4).

3. Artanto, Y. K. (2017). Bapongka, Sistem Budaya Suku Bajo Dalam Menjaga Kelestarian Sumber Daya Pesisir. Sabda :Jurnal Kajian Kebudayaan, 12(1), 52-69. https://doi.org/10.14710/sabda.v12i1.15253

4. Baskara, B. (2016). Islam Bajo: Agama Orang Laut. Banten: Javanica.

5. Bochner, A. P. (1988). Interpersonal Communication. In Encyclopedia of Communications, Edited by Erik Barnouw. Oxford: Oxford University Press.

6. Dayakisni, T. Y. (2008). Psikologi Lintas Budaya, EdisiRevisi. Malang: UMM Press.

7. De Block, D. (2009). Perlindungan Wilayah Pesisir Di Sulawesi: Mencermati Pendapat Masyarakat Pesisir. Warta TelukTomini, 7, September-November.

8. Fallding, H. (1974). The Sociology of Religion: An Explanation of the Unity and Diversity in Religion. McGraw: McGraw-Hill Ryerson Limited.

9. Gunawan, R., Digdoyo, E., \&Subarkah, A. (2014). Budaya Kearifan Lokal Dalam Tata Kelola Dan Pengembangan Ligkungan Kota. Sejarah Dan Budaya Tahun Kedelapan, 2.

10. Harun, R. (2011). KearifanLokal Masyarakat Bajo Dalam Melestarikan Lingkungan Pesisir Di Desa Torosiaje Kecamatan Popayato Kabupaten Pohuwato. Gorontalo: Universitas Negeri Gorontalo.

11. Indriastjario, \&Murtomo, B. A. (2015). Kajian Kearifan Lokal Untuk Pengembangan Wisata Waduk Jatibarang Kota Semarang. MODUL, 15(2), 125-32.

12. Kael, M., Hardiansyah, G., \& Iskandar. (2015). Kearifan Lokal Masyarakat Desa Tunggul Boyok Dalam Pengelolaan Madu Alam Di Kecamatan Bonti Kabupaten Sanggau. Jurnal Hutan Lestari, 3 (1).

13. Kafiar, F. P. (2013). Kearifan Lokal Suku Amungme Dalam Pengelolaan Sumber Daya Alam Dan Lingkungan Di Kabupaten Mimika Papua. Jurnal Ekosains, V(1).

14. Koentjaraningrat. (1964). Masyarakat Desa Di Indonesia Masa Ini. Jakarta: Balai Penerbitan Fakultas Ekonomi UI.

15. Moleong, L. J. (2007). Metodologi Penelitian Kualitatif, EdisiRevisi. Bandung: Remaja Rosda Karya.

16. Obie, M. (2015). Perampasan Hak Ulayat Pesisir Dan Laut Komunitas Suku Bajo (Kasus Pengelolaan Sumber Daya Pesisir Dan Laut Di Teluk Tomini). Bogor: Disertasi Sekolah Pascasarjana IPB.

17. Obie, M. (2016). Perubahan Sosial Pada Komunitas Suku Bajo Di Pesisir Teluk Tomini. Al-Tahrir: Jurnal Pemikiran Islam, 16(1), 153-74. https://doi.org/10.21154/al-tahrir.v16i1.377

18. Obie, M., Soetarto, E., Soemarti, T, \& Saharuddin. (2015). Sejarah Penguasaan Sumber Daya Pesisir dan Laut di Teluk Tomini. Paramita: Historical Studies Journal, 25(1). https://doi.org/10.15294/paramita.v25i1.3422

19. Pasandre, S., \&Sompah, A.(2018). Personal Communication.

20. Pasandre, U. (2017). Personal Communication.

21. Putra, R. (2013). Berladang Dan Kearifan Lokal Manusia Dayak. Jurnal Ultima Humaniora, 1(2).

22. Rahmadani, Y., Ermanto, \&Noveria, E. (2012). UngkapanLarangan Masyarakat Lubuak Sariak Kenagarian Kambang Kecamatan Lengayang Kabupaten Pesisir Selatan.Pendidikan Bahasa Dan Sastra Indonesia, 1(1), 330-38.

23. Renjaan, M. J., Purnaweni, H., \&Anggoro, D. D. (2013). Studi Kearifan Lokal Sasi Kelapa Pada Masyarakat Adat Di Desa Ngilng of Kabupaten Maluku Tenggara. Jurnal Ilmu Lingkungan, 11(1), 23-29. https://doi.org/10.14710/jil.11.1.23-29

24. Reza, M., \&Hidayati, A. N. (2017). Kearifan Lokal Suku Sasak Dalam Pengelolaan Sumber Daya Air Desa Lenek Daya, Kecamatan Aikmel Kabupaten Lombok Timur. Spectra,XV(30).

25. Santoso, I. (2006). Eksistensi Kearifan Lokal Pada Petani Tepian Hutan Dalam Memelihara Kelestarian Ekosistem Sumber DayaHutan.Wawasan: Jurnal Ilmiah Agama Dan Sosial Budaya, 11(3).

26. Sompah, J. (2018). Personal Communication. 
27. Sukmayadi, T. (2018). Nilai-Nilai Kearifan Lokal Dalam Pandangan Hidup Masyarakat Adat Kampung Kuta .JPK, Jurnal Pancasila Dan Kewarganegaraan, 3(1), 19-29. https://doi.org/10.24269/jpk.v3.n1.2018.pp19-29

28. Sulaiman. (2010). Kebijakan Pengelolaan Perikanan Berbasis Kearifan Lokal Di Aceh. Kanun, 50.

29. Sulastriyono, M. (2009). Nilai-Nilai Kearifan Lokal Dalam Pengelolaan Sumber Daya Air Di Telaga Omang Dan Ngloro Kecamatan Saptosari, Gunung Kidul Yogyakarta.Mimbar Hukum-Fakultas Hukum Universitas Gadjah Mada, 21(2), 243-55.

30. Surakhmad, W. (1982). Pengantar Penelitian Ilmiah: Dasar, Metode Dan Teknik. Bandung: Tarsito.

31. Syaufina, L., \& Tambunan, F. G. S. (2013). Kearifan Lokal Masyarakat Adat Dalam Mencegah Kebakaran Hutan Dan Lahan. JURNAL SILVIKULTURA TROPIKA, 4(3).

32. Thamrin, H. (2013). Kearifan Lokal Dalam Pengelolaan Lingkungan. Khutubkhanah, 161.

33. Uniawati. (2014). Perahu Dalam Pamali Orang Bajo: Tinjauan Semiotika Sosial Halliday. Jurnal Pendidikan Dan Kebudayaan, 20(4). https://doi.org/10.24832/jpnk.v20i4.166

34. Utina, R. (2012). Kecerdasan Ekologis Dalam Kearifan Lokal Masyarakat Bajo Desa Torosiaje Provinsi Gorontalo. Prosiding Konferensi Dan Seminar Nasional Pusat Studi Lingkungan Hidup Indonesia Ke 21, 13-15 September.

35. Utina, R.,\&Alwiah. (2008). Bapongka: Studi Nilai Pendidikan PelestarianEkosistemLaut Dan Pesisir Pada Masyarakat Bajo. Journal Matsains, 2(3).

36. Zacot, F. R. (1982). Orang Bajo Suku Pengembara Laut: Pengalaman Seorang Antropolog. Penerjemah Laure F.M., Pranoto I.B. Jakarta: Kepustakaan Populer Gramedia (KPG) bekerjasamadengan Ecolo Francaised' Extreme-Orient dan Forum Jakarta-Paris.

37. Zulharman, J., Khaldun, I., \& Santoso, H. (2017). Kearifan Lokal Masyarakat Desa Sambori Dalam Pengelolaan Sumberdaya Alam Dan Potensi Ekowisata. JIME, 3(2).

38. Zulkarnain. (2009). Kearifan Lokal Dalam Pemanfaatan Dan Pelestarian Sumber Daya Pesisir (Studi Kasus Di Desa Panglima Raja Kecamatan Concong Kabupaten Indragiri Hilir Provinsi Riau. Berkala Perikanan Terubuk, 37(2). 